\title{
CONTEXTO GEOLÓGICO E POTENCIAL MINERAL DO GRANITO SERRA DO PARATIÚ, CANANÉIA, ESTADO DE SÃO PAULO \\ FERNANDO ANTONIO GUIMARÃES MARTINS*
}

\author{
DISSERTAÇÃO DE MESTRADO - Programa de Pós-Graduação em Geologia - UFPR \\ DATA DE DEFESA: 23 ago. 02
}

O trabalho desenvolvido, e que substancia esta dissertação de mestrado, teve como principal objetivo efetuar a caracterização petrográfica, petrogenética, geoquímica e metalogenética, assim como promover uma avaliação do potencial mineral do Maciço granítico Serra do Paratiú. Neste contexto, foram enfocadas as mineralizações associadas com rochas graníticas em geral, e, em particular, os vários corpos granitóides mineralizados do estado de São Paulo, onde se encontram mineralizações polimetálicas com $\mathrm{Cu}, \mathrm{Zn}, \mathrm{Pb}$ e Sn (e.g. Granito Correas, Granito Mandira, Granito Guaraú, Granito São Francisco e Granito Itu). Os modelos conceituais básicos que nortearam a pesquisa dos metais acima foram os modelos de depósitos apicais do tipo greisens e periféricos do tipo filoneanos hidrotermais e metassomáticos. Para o entendimento e melhor interpretação dos trabalhos, foi efetuado um mapeamento geológico do corpo granítico, suas encaixantes e coberturas. O mapeamento geológico, na escala aproximada 1:38.500, abarcou uma área de $210 \mathrm{~km}^{2}$, onde se identificou, além do Granito Serra do Paratiú, rochas metamórficas do Complexo Turvo-Cajati, nas quais o corpo granítico acha-se intrudido; formações sedimentares Plio-Pleistocências do Grupo Mar Pequeno (Formação Cananéia e, muito subordinadamente, as Formações Pariquera-Açu e llha Comprida) e coberturas holocênicas de origem continental, marinha e mista. O maciço Granítico Serra do Paratiú (Neoproterozóico Eopaleozóico) está inserido na Plataforma Sul Americana, no contexto geotectônico do embasamento cristalino sul-sudeste brasileiro. Constitui-se de um corpo, de forma levemente ovalada, com aproximadamente $100 \mathrm{~km}^{2}$ de áreas, dos quais $30 \%$ acham-se encobertos por sedimentos cenozóicos. Trata-se de um corpo circunscrito, discordante e relativamente muito homogêneo, constituído por biotita monzogranito (granito 3b), que apre- senta textura porfírica e, subordinadamente, porfiróide, com matriz granular hipidiomórfica, de granulação media, localmente fina e/ou grossa, de tonalidade esbranquiçada a acinzentada. Em termos gerais constitui-se em média por 30-40\% de microclínio, 25-30\% de quartzo, 25 - $30 \%$ de plagioclásio e 5 - $10 \%$ de biotita. Como acessórios ocorrem: zircão, epidoto, apatita, sericita-moscovita, clorita, fluorita, titanita, hidróxidos de ferro e outros opacos. Muito localmente ocorre biotita sienogranito (granito 3a). Acha-se intrudido em metamórficos do Complexo Turvo-Cajati (Paleoproterozóico), onde, localmente, junto ao contato, verifica-se biotita-cordieirita horsnfels denotando termometamorfismo de contato. O granito Serra do Paratiú é fracamente peraluminoso, do tipo "subsolvus", e colocase nos termos finais da série cálcio-alcalina. Os dados petroquímicos permitem posicioná-lo como um granito mais pertinente à classe dos granitos pós-colisionais, variável de pós-tectônico a anarogênico, com dados composicionais, relativos a alguns elementos ( $\mathrm{Y}, \mathrm{Nb}, \mathrm{Rb}$, $\mathrm{Zr}$ ) e óxidos $\left(\mathrm{SiO}_{2}, \mathrm{~K}_{2} \mathrm{O}\right)$, que permitem visualizá-lo ora como tipo A, formado por fusão da crosta inferior, altamente fracionada, à semelhança do que ocorre com os granitos australianos Ackley e Sandy cape, cujas características geoquímicas são compatíveis com os granitos do tipo A, mas geológica e petrograficamente são respectivamente, granitos do tipo I e S. A hipótese de que o Granito Serra do Paratiú seja pós-orogênico é reforçada pelas evidências de campo (forma do corpo, metamorfismo de contato) e petroquímicas. Os granitos da Suíte Serra do Mar, da qual o Granito Serra do Paratiú faz parte, apresentam idades radiométricas próximas de $580 \pm 20 \mathrm{Ma}$. Concomitantemente ao trabalho de mapeamento geológico deste Maciço granítico, efetuouse, em seu domínio, a coleta de 286 amostras de sedimentos ativos de corrente, que foram analisadas para os

* e-mail: fagm@mail.pt 
elementos $\mathrm{Cu}, \mathrm{Zn}, \mathrm{Pb}, \mathrm{Li}$, Mo e Bi por absorção atômica; F por eletrodo de íon seletivo; e Sn por colorimetria; e 106 amostras de concentrados de bateia que foram submetidas a análises mineralógicas. Como resultado do tratamento estatístico dos dados obtidos das análises de sedimentos de corrente, associados àqueles obtidos com os estudos efetuados nos concentrados de bateia, foram identificadas nove zonas geoquimicamente anômalas representadas pelas associações dos elementos acima, as quais foram objeto de pesquisas prospectivas de detalhe, porém nenhuma mineralização foi constatada a elas associadas. A integração de todos os dados obtidos durante esta pesquisa permitiu concluir que o Granito Serra do Paratiú corresponde a um granito estéril, do ponto de vista de exploração mineral, e que sua esterilidade deve-se a um conjunto de situações desfavoráveis, tais como: ausência de um protolito enriquecido em metal; não houve desenvolvimento de uma fase de pré-concentração durante a evolução magmática; presença de um conjunto de minerais acessórios cafêmicos e seqüestradores de metal na fase magmática precoce (ilmenita, magnetita etc); e liberação precoce da fase aquosa, prejudicando qualquer compensação e sucesso de concentração hidrotermal. 